\title{
Short communication: Evaluation of serum immunoglobulin G concentrations using an automated turbidimetric immunoassay in dairy calves
}

\author{
M. L. Alley, ${ }^{* 1}$ D. M. Haines, $\dagger$ and G. W. Smith* \\ ${ }^{*}$ Department of Population Health and Pathobiology, College of Veterinary Medicine, North Carolina State University, Raleigh 27607 \\ †Department of Veterinary Microbiology, Western College of Veterinary Medicine, University of Saskatchewan, Saskatoon, SK, Canada S7N 5B4
}

\begin{abstract}
The absorption of maternal antibodies associated with colostrum feeding is critical to the health of calves. Multiple assays have been described to assess serum immunoglobulin G (IgG) concentrations in calves. However, none are ideal for routine use on farms. The purpose of this study was to evaluate the reliability of a new commercially available immunoassay and portable analyzer for measuring serum IgG concentrations in dairy calves. Serum from 100 Holstein calves that had received colostrum was collected for this study. Immunoglobulin $\mathrm{G}$ concentrations were run on each calf using both the rapid immunoassay method and radial immunodiffusion assay. Serum IgG concentrations in calves from this study ranged from 460 to $3,640 \mathrm{mg} / \mathrm{dL}$ (mean \pm SD: $1,515 \pm 71$ ) as measured by radial immunodiffusion and 402 to $3,586 \mathrm{mg} / \mathrm{dL}$ (mean 1,473 \pm 70 ) as measured by the immunoassay. Based on regression analysis, the automated results closely paralleled those obtained by radial immunodiffusion with a coefficient of determination value of 0.98 . Based on the results of this study, the immunoassay technique using the portable analyzer represents a reliable method that can be run within $15 \mathrm{~min}$ and provide an accurate serum IgG level. Although the cost is not insignificant, this assay could be easily implemented on a dairy farm to help monitor transfer of passive immunity.
\end{abstract}

Key words: failure of passive transfer, immunoglobulin G measurement, immunoassay, colostrum

\section{Short Communication}

Administration of colostrum to newborn calves is recognized as an important component of dairy calf health maintenance, as colostral Ig absorption is required to establish passive immunity. Current recommendations are to feed 3 to $4 \mathrm{~L}$ of high-quality (>50 g of $\mathrm{IgG} / \mathrm{L}$

Received February 8, 2012.

Accepted April 12, 2012.

${ }^{1}$ Corresponding author: Mark_alley@ncsu.edu and $<100,000 \mathrm{cfu}$ of total bacteria $/ \mathrm{mL}$ and $<10,000$ cfu of coliform bacteria/mL) colostrum to dairy calves within $6 \mathrm{~h}$ of birth to protect against failure of transfer of passive immunity (Weaver et al., 2000; McGuirk and Collins, 2004; Chigerwe et al., 2008). Despite the importance of a good colostrum management program, over one-third $(36.3 \%)$ of dairy operations still depend on the calf nursing the dam as the only method for colostrum delivery, and $19.2 \%$ of calves are estimated to have failure of transfer of passive immunity (FTPI; NAHMS, 2007). Failure of transfer of passive immunity is generally defined as a serum IgG concentration of $<1,000 \mathrm{mg} / \mathrm{dL}$ in calves between 1 and $7 \mathrm{~d}$ of age (Tyler et al., 1996; Weaver et al., 2000; Godden, 2008), and has been associated with an increased risk of morbidity and mortality, decreased growth rates, and decreased first-lactation milk production (Tyler et al., 1999; Virtala et al., 1999; Faber et al., 2005).

Several assays are available for evaluating the adequacy of transfer of passive immunity in neonatal calves (Tyler et al., 1996; Parish et al., 1997; Weaver et al., 2000). Radial immunodiffusion (RID) was described over 40 yr ago and has long been considered the gold standard for determining IgG concentrations in calves (McBeath et al., 1971). It provides quantitative results; however, its usefulness for herd monitoring is limited because of the extended time required for results to be available. Refractometry and serum total protein measurements have also been used for many years (McBeath et al., 1971) but are unreliable in moribund or dehydrated calves. Other assays such as the sodium sulfite turbidity test, zinc sulfate turbidity test, ELISA, serum $\gamma$-glutamyl transferase activity, and whole blood glutaraldehyde coagulation test have been previously described with varying degrees of accuracy for predicting IgG concentrations in calves (Tyler et al., 1996; Parish et al., 1997; Weaver et al., 2000). However, most of these assays (including total protein, serum $\gamma$-glutamyl transferase, and the glutaraldehyde coagulation test) are qualitative and only give an estimate of serum IgG levels.

An automated immunoassay for detecting IgG concentrations in calf serum or plasma has been previously 
described (Etzel et al., 1997). It has been shown to be an accurate and precise analytical method when run in a laboratory setting. Recently, a new rapid immunoassay has become commercially available that is designed to be run with a small portable laboratory instrument. This quantitative test provides an exact IgG concentration within 10 to $15 \mathrm{~min}$. If the test were reliable, it could be kept on farm and easily used by dairy producers or veterinarians (or both) for monitoring transfer of passive immunity status in calves. The purpose of this study was to compare serum IgG concentrations measured by the immunoassay to those obtained by RID in dairy calves.

The study protocol was approved by the North Carolina State University institutional committee on the care and use of laboratory animals. Blood samples were collected from 100 calves between 1 and $5 \mathrm{~d}$ of age. Calves were all Holsteins and came from 5 different dairy farms visited by the Production Medicine group at North Carolina State University (Raleigh). All calves had received colostrum after birth according to herd records. Blood samples were collected from the jugular vein of each calf into plain glass tubes and allowed to clot. Serum was removed and stored at $-4^{\circ} \mathrm{C}$ until analyzed. Serum samples were analyzed for IgG by RID assay and an immunoassay.

The RID assay used in the study has been previously validated for use in calves (Chelack et al., 1993). A bovine IgG sample obtained from the US Department of Agriculture Center for Veterinary Biologics was used as the reference sample. The IgG of the reference sample had been measured by turbidometric assay (Etzel et al., 1997) and was reported to be $3,204 \mathrm{mg} / \mathrm{dL}$. The reference sample was diluted 1:3 with PBS before use in the assay. The RID assay incorporates an antiserum that is both heavy- and light-chain reactive, detecting both $\operatorname{IgG}_{1}$ and $\operatorname{Ig} \mathrm{G}_{2}$.

The commercially available immunoassay (bovine serum/plasma IgG; Midland BioProducts Corp., Boone, IA) was conducted according to the product instructions using a portable analyzer (MBC QTII; Midland BioProducts Corp.). Briefly, reagent vials were allowed to warm to room temperature before running the assays. Ten microliters of serum were then added to each reagent vial using the calibrated pipette provided with the portable analyzer. Following a 5- to 10-min incubation period, the reagent vials were inserted into the portable analyzer and the IgG concentration was immediately reported. For calves with IgG concentrations greater than $1,750 \mathrm{mg} / \mathrm{dL}$, serum samples had to be diluted (1:2) with saline and run again. For these samples, $100 \mu \mathrm{L}$ of saline was combined with $100 \mu \mathrm{L}$ of serum (using the pipette provided with the analyzer).
From this mixture, $10 \mu \mathrm{L}$ was added to a reagent vial and the test repeated.

Data are presented as mean \pm standard deviation. Summary statistics and the coefficient of variation for both assays were calculated. Concentrations of IgG, as determined by RID, were compared with those found via the immunoassay using linear regression. Both the correlation coefficient and the coefficient of determination were determined. A 2-tailed Student's $t$-test was also conducted and $P<0.05$ was considered significant.

Serum IgG concentrations in the 100 calves in this study ranged from 460 to $3,640 \mathrm{mg} / \mathrm{dL}$ (mean 1,515 $\pm 71)$ as measured by RID and 402 to $3,586 \mathrm{mg} / \mathrm{dL}$ (mean $1,473 \pm 70$ ) as measured by the immunoassay. The coefficient of variation was similar for both assays (47.1\% for RID and $47.2 \%$ for immunoassay). Based on regression analysis, the automated immunoassay results closely paralleled those obtained by RID (Figure 1). The correlation coefficient was 0.988 and the coefficient of determination value between the 2 assays was 0.98 . Results of the $t$-test indicated that the assays were not significantly different.

Forty-nine out of the 100 serum samples run by immunoassay had serum IgG concentrations within 50 $\mathrm{mg} / \mathrm{dL}$ of the RID results. Thirty-four calves had results that differed by 50 to $100 \mathrm{mg} / \mathrm{dL}, 10$ differed by 100 to $200 \mathrm{mg} / \mathrm{dL}$, and 7 differed by more than $200 \mathrm{mg} / \mathrm{dL}$. The larger variations were typically observed at higher measured IgG levels. For example, the 2 largest deviations between the assays in this study were $388 \mathrm{mg} / \mathrm{dL}$ $(1,852 \mathrm{mg} / \mathrm{dL}$ as measured by immunoassay and 2,240 as measured by RID) and $382 \mathrm{mg} / \mathrm{dL}(3,258 \mathrm{mg} / \mathrm{dL}$ as measured by immunoassay and 3,640 as measured by RID). It should be noted, however, that several serum samples with very high IgG concentrations correlated very well between the 2 assays (for example, 1 sample reported an $\mathrm{IgG}$ concentration of $3,586 \mathrm{mg} / \mathrm{dL}$ by immunoassay and $3,610 \mathrm{mg} / \mathrm{dL}$ by RID). Ultimately, the 2 assays demonstrated very good correlation and $83 \%$ of all samples run by the immunoassay method had an IgG concentration within $100 \mathrm{mg} / \mathrm{dL}$ of the RID. This demonstrates the assay and portable analyzer would be reliable for monitoring transfer of passive immunity on dairy farms.

The assay used in this study uses an immunoturbidimetric method to measure bovine IgG that has been previously described (Etzel et al., 1997). This immunoassay has been available for several years and has been shown to perform well in calves (Dawes et al., 2002) and foals (Davis et al., 2005). This test was originally designed to be run in a clinical laboratory setting and required equipment that would preclude it from being used routinely on a farm or in a veterinary practice. 


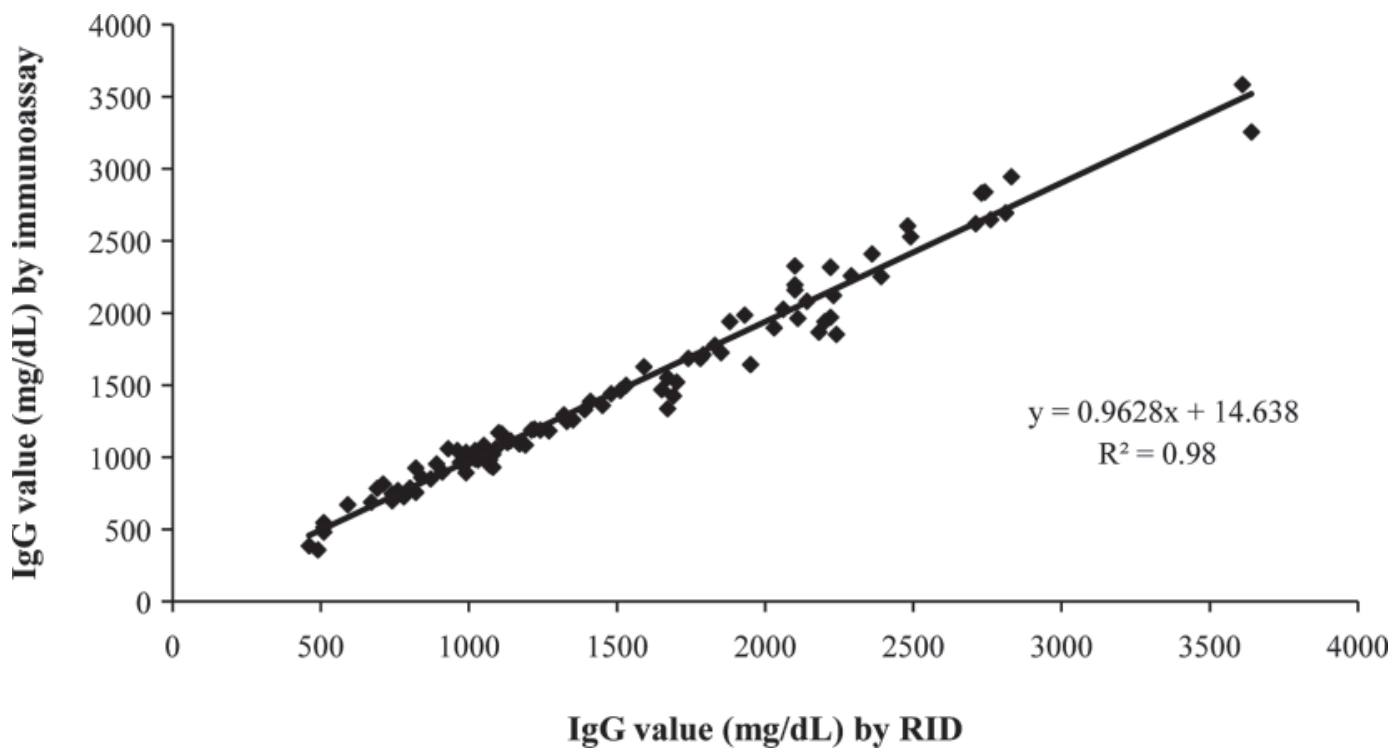

Figure 1. Regression between serum IgG concentrations in 100 dairy calves as measured by an automated immunoassay and radial immunodiffusion (RID).

However, a small portable analyzer (MBC QTII) has been developed for use with the immunoassay that makes this method very practical. The instructions are easy to follow and it would be simple to train farm personnel to run. The portable analyzer can also be used with other commercially available test kits to measure serum calcium, magnesium, and phosphorus concentrations in cattle (Midland BioProducts Corp.), which could increase its value on a farm. Although the individual immunoassay tubes are about $\$ 7$ each, the immunoassay provides an actual IgG concentration that can be used in dehydrated calves. Due to the cost involved, this test might not be appropriate for all farms; however, in certain dairies it may prove to be useful. An example would include a dairy farm that is having a significant problem with diarrhea in calves less than 2 wk of age. Using the immunoassay in such a herd to get an actual IgG concentration might be more valuable in terms of monitoring the effectiveness of a colostrum program as compared with serum total protein concentrations.

Serum total protein concentrations have previously been shown to be fairly well correlated with IgG concentrations $\left(\mathrm{R}^{2}=0.72\right)$ as measured by RID (McBeath et al., 1971). Another study demonstrated that a serum total protein concentration of $5.2 \mathrm{~g} / \mathrm{dL}$ was roughly equivalent to an IgG concentration of 1,000 $\mathrm{mg} / \mathrm{dL}$ (Tyler et al., 1996). Therefore, most programs that use serum total protein concentrations to monitor the adequacy of transfer of passive immunity use the value of $5.2 \mathrm{~g} / \mathrm{dL}$ as a cutoff value to categorize calves as adequate colostrum ingestion or failure of passive transfer. Although this is useful information, the immunoassay will give more precise data and is better correlated with actual IgG concentration as compared with refractometry.

In this study, out of the 100 dairy calves that we sampled from multiple herds, $24 \%$ had IgG concentrations $<1,000 \mathrm{mg} / \mathrm{dL}, 33 \%$ were between 1,000 and 1,600 $\mathrm{mg} / \mathrm{dL}, 26 \%$ were between 1,600 and 2,400 $\mathrm{mg} / \mathrm{dL}$, and $17 \%$ of calves had IgG concentrations $>2,400 \mathrm{mg} / \mathrm{dL}$. In the dairy industry, FTPI has long been defined as an IgG of $<1,000 \mathrm{mg} / \mathrm{dL}$ (Tyler et al., 1996; Weaver et al., 2000; Godden, 2008); however, it could be argued that the goal should be set higher. Several studies in beef calves have demonstrated that higher levels of serum IgG seem to convey additional protection against disease. For example in a study of 1,568 beef calves, those with an $\operatorname{IgG}$ concentration $>1,600 \mathrm{mg} / \mathrm{dL}$ had a significant reduction in both morbidity and mortality compared with calves with IgG concentrations below $1,600 \mathrm{mg} / \mathrm{dL}$ (Dewell et al., 2006). In addition, calves with even higher $\operatorname{IgG}$ concentrations $(>2,400 \mathrm{mg} / \mathrm{dL})$ were 1.6 times less likely to become ill before weaning and were 2.7 times less likely to die before weaning compared with calves with IgG concentrations between 1,200 and $2,000 \mathrm{mg} / \mathrm{dL}$. In another study, serum IgG concentrations of 935 beef calves from 152 herds in Western Canada were compared with health and mortality rates of calves through weaning (Waldner and Rosengren, 2009). This study found that the optimal IgG threshold to limit mortality and the odds of the calf having to be treated for disease was $2,400 \mathrm{mg} / \mathrm{dL}$. Although similar data are not available in dairy calves, 
perhaps the recommended target of $1,000 \mathrm{mg} / \mathrm{dL}$ is too low.

The use of an assay that provides an actual IgG concentration would be helpful for a farm that wanted to determine exactly how they were doing with their colostrum program. It certainly could be argued that because Holstein colostrum contains a lower concentration of IgG compared with most breeds of beef cattle, very high IgG concentrations are an unrealistic goal in dairy calves. However, with the early collection of clean colostrum from the cow, combined with feeding an adequate volume to the calf in a timely manner, higher levels of IgG can be achieved. For example, one study reported an average serum IgG concentration of $2,720 \pm 1,020$ in a group of 21 Holstein calves that were fed 4 quarts of colostrum within $3 \mathrm{~h}$ of birth (Foster et al., 2006).

Regardless of the IgG value used to define FTPI on a farm, it is clear that the dairy industry needs to do a better job monitoring transfer of passive immunity status in calves. Despite 25 to $30 \%$ of dairy calves consistently having IgG concentrations $<1,000 \mathrm{mg} / \mathrm{dL}$, the last National Animal Health Monitoring Survey (NAHMS) in 2007 found that only $2 \%$ of dairy farms used total protein or any other method to evaluate their colostrum management program (NAHMS, 2007). The immunoassay and portable analyzer represent a reliable method for determining IgG concentrations in calves and could be easily used by dairy producers or veterinarians.

\section{ACKNOWLEDGMENTS}

The portable analyzer (MBC QTI) and immunoassay used in this study were donated by Midland BioProducts Corp. (Boone, IA).

\section{REFERENCES}

Chelack, B. J., P. S. Morley, and D. M. Haines. 1993. Evaluation of methods for dehydration of bovine colostrum for total replacement of normal colostrum in calves. Can. Vet. J. 34:407-412.

Chigerwe, M., J. W. Tyler, L. G. Shultz, J. R. Middleton, B. J. Steevens, and J. N. Spain. 2008. Effect of colostrum administration by use of oroesophageal intubation on serum IgG concentrations in Holstein bull calves. Am. J. Vet. Res. 69:1158-1163.
Davis, D. G., D. M. W. Schaefer, K. W. Hinchcliff, M. L. Wellman, W. E. Willet, and J. M. Fletcher. 2005. Measurement of serum IgG in foals by radial immunodiffusion and automated turbidimetric immunoassay. J. Vet. Intern. Med. 19:93-96.

Dawes, M. E., J. W. Tyler, D. Hostetler, J. Lakritz, and R. Tessman. 2002. Evaluation of a commercially available immunoassay for assessing adequacy of passive transfer in calves. J. Am. Vet. Med. Assoc. 220:791-793.

Dewell, R. D., L. L. Hungerford, J. E. Keen, W. W. Laegreid, D. D. Griffin, G. P. Rupp, and D. M. Grotelueschen. 2006. Association of neonatal serum immunoglobulin G1 concentration with health and performance in beef calves. J. Am. Vet. Med. Assoc. 228:914-921.

Etzel, L. R., R. E. Strohbehn, and J. K. McVicker. 1997. Development of an automated turbidimetric immunoassay for quantification of bovine serum immunoglobulin G. Am. J. Vet. Res. 58:1201-1205.

Faber, S. N., N. E. Faber, T. C. McCauley, and R. L. Ax. 2005. Effects of colostrum ingestion on lactational performance. Prof. Anim. Sci. 21:420-425.

Foster, D. M., G. W. Smith, T. R. Sanner, and G. V. Busso. 2006. Serum IgG and total protein concentrations in dairy calves fed two colostrum replacement products. J. Am. Vet. Med. Assoc. 229:1282-1285.

Godden, S. 2008. Colostrum management for dairy calves. Vet. Clin. North Am. Food Anim. Pract. 24:19-39.

McBeath, D. G., W. J. Penhale, and E. F. Logan. 1971. An examination of the influence of husbandry on the plasma immunoglobulin level of the newborn calf, using a rapid refractometer test for assessing immunoglobulin content. Vet. Rec. 88:266-270.

McGuirk, S. M., and M. Collins. 2004. Managing the production, storage, and delivery of colostrum. Vet. Clin. North Am. Food Anim. Pract. 20:593-603.

NAHMS (National Animal Health Monitoring System). 2007. Dairy 2007. Part 1: Reference of Dairy Cattle Health and Management in the United States. US Department of Agriculture Animal and Plant Health Inspection Service (USDA-APHIS) Veterinary Services, Ft. Collins, CO.

Parish, S. M., J. W. Tyler, T. E. Besser, C. G. Gay, and D. Krytenberg. 1997. Prediction of serum IgG1 concentration in Holstein calves using serum gamma glutamyltransferase activity. J. Vet. Intern. Med. 11:344-347.

Tyler, J. W., D. D. Hancock, S. M. Parish, D. E. Rea, T. E. Besser, S. G. Sanders, and L. K. Wilson. 1996. Evaluation of 3 assays for failure of passive transfer in calves. J. Vet. Intern. Med. 10:304-307.

Tyler, J. W., D. D. Hancock, J. Thorne, C. C. Gay, and J. M. Gay. 1999. A model partitioning the risk of mortality associated with inadequate passive transfer in dairy calves. J. Vet. Intern. Med. $13: 335-337$.

Virtala, A. M. K., Y. T. Gröhn, G. D. Mechor, and H. N. Erb. 1999. The effect of maternally derived immunoglobulin $\mathrm{G}$ on the risk of respiratory disease in heifers during the first 3 months of life. Prev. Vet. Med. 39:25-37.

Waldner, C. L., and L. B. Rosengren. 2009. Factors associated with serum immunoglobulin levels in beef calves from Alberta and Saskatchewan and association between passive transfer and health outcomes. Can. Vet. J. 50:275-281.

Weaver, D. M., J. W. Tyler, D. C. VanMetre, D. E. Hostetler, and G. M. Barrington. 2000. Passive transfer of colostral immunoglobulins in calves. J. Vet. Intern. Med. 14:569-577. 